\title{
5 Social justice and the persistence of racialized segregation
}

\author{
Kevin Durrheim and Amy Jo Murray
}

When the heady days of social transformation begin to recede into history, they often leave behind a sense of bitter disappointment over lost opportunities. This has certainly been the case in South Africa. The struggle for change had been informed by cultivated ideals of justice, equality and nonracialism, as expressed in the Freedom Charter of 1955. The process of change was glorious: the liberation movements were unbanned; leaders including Nelson Mandela were released from prison; joyous protests erupted nationwide and democratic elections followed; resulting in the formation of a representative government and the scrapping of apartheid legislation. Thereafter began the gradual process of reshaping the ideology and demography of the economy, the social body, and public and private institutions.

But the post-apartheid reality has continued to be marked by deep injustices, inequalities, violence, racial division and conflict (Tshishonga 2019). The murmuring of discontent is as loud as ever. It is carried through the air via disparate voices of protest: fallist movements, ${ }^{1}$ factionalism, taxi wars, service delivery protests and the resurgent right, to name but a few. The murmuring is also felt in the ground, reverberating through the reality of unemployment, murder, gender-based violence, racist attacks, hate speech, unequal access to health, education and social services, income inequality, xenophobia, and so on. Pain, anger, guilt, shame, desperation, disappointment and insecurity make a toxic brew of post-apartheid affect (Nyamnjoh 2016).

This chapter sets out with the ambition of explanation. What went wrong? South Africans had good leaders, international support, good economic years and a majority who were genuinely committed to change. How was it possible to fail so badly? One avenue of enquiry, we propose, is the way new patterns of segregation emerged from the ruins of apartheid. These took shape from the substance of apartheid. Townships remained poor and black - albeit with newly acquired municipal services in many instances. Mushrooming informal settlements on the urban periphery also remained deeply poor and black, and became increasingly pan-African. The old urban centres, once the high-value real estate of capital and consumption, fell into ruin and decay as the white inhabitants withdrew their persons and

DOI: $10.4324 / 9781003167280-7$ 
investments. At the same time, in the greatest collective investment and expenditure of wealth in the history of the country, new sites of exclusivity were built from the ground up. Exclusive estates and gated communities, shopping malls, wine farms, office parks, and edge cities created new spaces of residence, consumption, labour and leisure. The geography is not a replica of the rigidly partitioned atlas of apartheid (Christopher 2000), but it echoes the major themes. The post-apartheid geography offers many sites and opportunities for inter-racial contact and exchange, but the reality is that segregation persists both in structures and micro-ecologies.

In this chapter we briefly review the literature that shows why intergroup contact can be a powerful vehicle for change, but why this potential is not realized in persistently segregated contexts. We then focus on forms of migration by which patterns of segregation are re-laid in contexts of transformation. Migration and segregation create new spaces of exclusivity with barriers to entry that help to preserve and re-establish (racialized) inequality. They also help to produce a new aspirational and symbolic order that undermines transformative justice.

\section{Contact theory and the problem of segregation}

Social scientists have long touted desegregation as a mechanism of social change. As early as 1903, W.E.B. Du Bois (1903 p. 32) proclaimed that "the problem of the twentieth century is the problem of the color-line". In his haunting account of the colonial "European sector" and "Native sector", Fanon (1961) showed how inequality and a psychology of oppression took shape around spatial segregation. Later, Pettigrew (1979 p. 122) described segregation as a "structural lynchpin" of intergroup relations, which held together prejudiced attitudes, discriminatory practices, norms of exclusion and a slew of economic inequalities. Around the world, forms of segregation based on ethnicity, religion, autochthony and class have evolved together with racial segregation into a global tapestry of "color-lines" that have persisted well into the twenty-first century.

Given the universality of the problem of segregation, it is unsurprising that a substantial body of work within the social sciences has held desegregation as an objective and ideal of transformative justice (Dixon et al. 2017). This work gathered momentum during the civil rights movement in the USA in the 1950s. Social scientists provided evidence to support the legal challenge to school segregation in the US Supreme Court, showing the negative consequences of segregation and potential positive effects of desegregation for challenging racist attitudes (see Clark 1953). The message was clear: transformative justice would only be achieved by desegregation - and the Supreme Court Justices agreed!

A great deal of research over the past 70 years has supported the hypothesis - formulated by Gordon Allport (1954) as the "contact hypothesis" that intergroup contact under optimal conditions (such as equal status 
cooperation) reduces intergroup prejudice (Pettigrew and Tropp 2006; Kende et al. 2018). This work has progressively clarified the underlying mechanisms. Contact is effective in reducing prejudice when it leads to common identification (Gaertner et al. 1996), when it fosters intergroup empathy and reduces anxiety (Pettigrew and Tropp 2008), and when it allows intergroup friendships to develop (Turner et al. 2007). We also now understand that direct contact is not necessary but that indirect contact with ingroup members who have contact with outgroup members (Wright et al. 1997; Zhou et al. 2019), or even imagining contact (Crisp and Turner 2009) with outgroup members, can also have the effect of reducing prejudice. A recent meta-analysis confirms that contact interventions are effective for reducing prejudice in real world settings outside of the lab (Lemmer and Wagner 2015).

However, over the years there have also been persistent nagging concerns, especially for the efficacy of contact interventions in segregated societies and societies in conflict (Dixon et al. 2005; Maoz 2011). First, negative contact appears to be more powerful in promoting prejudice than positive contact is in reducing it (Barlow et al. 2012). Second, although effective in reducing prejudice, positive contact can also have a "sedative effect" undermining the resolve of oppressed groups to engage in collective action and promote change (Cakal et al. 2011; Dixon et al. 2007). This is especially important in contexts like transformed South Africa, where new elites from the former oppressed groups now have full access to racially integrated places and institutions of economic privilege. Third, and most fundamentally, although friendship and positive contact can promote positive change, the problem in many societies is that such contact is hardly ever attained. Even when it is, or when one experiences extended or imagined positive contact, its affects risk being drowned by the negative experiences, stories and threats that proliferate in socially, economically and institutionally conflicted and segregated societies (Bettencourt et al. 2019).

Pettigrew and Hewstone (2017) have advocated for more sophisticated technical and statistical solutions to these problems. They argue that better studies, and multilevel analyses that take into account the effect of contextual factors (e.g. structural, economic and political), will more clearly identify the individual-level effects of contact on prejudice reduction. They believe that such work will show that contact works and is an even more powerful change agent than previously thought. However, this still leaves an open question about how to promote social change in segregated societies. The original impetus of contact research was societal transformation in the pursuit of social justice (Durrheim and Dixon 2018). Taking contextual factors into account when modelling the effect of contact on attitudes is good science but it is not sufficient in itself to address the political, economic, geographic or psychological solutions to the problem of segregation.

With this objective in mind, we will consider how patterns of migration and segregation work to set up broader attitudes and intergroup relations, and when social change sets in motion practices of migration that undermine 
the creation of more social justice. We will use the work of I.D. MacCrone (1933) to demonstrate the importance of migration and to paint a historical background to the South African case. Our main message is that transformative justice (Evans 2016) is not accomplished by prejudice reduction although this would be ideal and contact can help - but by changing patterns of migration which help to constitute the intergroup context.

\section{Migration and race attitudes on the colonial frontier and beyond}

MacCrone (1933) developed a historical and functional analysis of group prejudice that underpinned apartheid. White prejudices fulfilled functions of group preservation in the context they found themselves in as a minority in Africa, and helped them to preserve their unity, identity and economic interests (MacCrone 1933). These attitudes, he argues, had developed in a specific context of intergroup contact between European settlers and African autochthons. When the Dutch arrived to set up a fort and garden in the Cape in 1652, under Dutch law, they were to leave the native people "undisturbed in their liberty and never enslaved" (p. 47). Nonetheless, the contact situation of exploitative trade and land encroachment fostered an attitude of "increasing dislike and contempt" (p. 47). Within 50 years, the local clans had become so impoverished through their interactions with the European settlers that they needed to be "supplied by the Company with cattle to tend on shares" (MacCrone 1957, p. 82).

Later, in a quest for grazing land and independence, the settlement began expanding outward as Europeans migrated into the interior. In the process, a frontier was established. The frontier was less a boundary line than "the outer edge of the wave - the meeting point between savagery and civilization" (Turner, cited in MacCrone 1957, p. 99). It was here that the psychosocial situation of the settler community developed. The frontier was a site of ongoing expansion and disposition that produced an "atmosphere of war" in which race attitudes assumed "extreme or exaggerated forms of expression" (p. 125). The meaning of the racially charged slur "kaffir" was formed in this context to refer to Africans as "savage, subhuman, treacherous, thieving, indolent, merciless" (Arndt 2018, p. 74).

MacCrone argues that this psychosocial situation extended into the twentieth century, carrying along its racist attitudes. Migration shifted from the frontier as economic opportunities were found in towns and cities. As was always the case, colonizers were dependent on the African population for labour, but now the whites who settled in towns and cities attempted to regulate the migration of Africans into and out of cities. This culminated in the "highest stage of white supremacy" (Cell 1982) - the apartheid system (implemented from 1948 at the election of the National Party) - of pass control, forced removals and rigid, universal de jure racial segregation. This situation prompted something of an attitudinal inversion. In contrast to the hostile frontier, apartheid discourse portrayed idyllic images of rural Africa 
and contented Africans, but viewed city life as a contaminating site for Africans, and "dressed natives" as corrupted (Packard 1989).

\section{The post-apartheid case}

With the end of apartheid in 1994, through South Africa's first fully democratic elections, came a process of transformational justice. Discourses of a "Rainbow Nation" were promoted, presenting hopes of all South Africans moving forward and working together to form a new, post-apartheid South Africa where diversity, justice, freedom, equality, unity and inclusion would become celebrated norms. South Africa would be transformed, especially in the arena of social justice which had largely been undermined through apartheid's system of racial segregation and exclusion. Places of work, education, leisure, commerce and residential communities were officially accessible and open to all citizens.

However, the transition from apartheid through free and fair elections, and mechanisms such as the Truth and Reconciliation Commission (TRC), did not lead to social justice. As is discussed by Tim Murithi in Chapter 2 in this volume, while the TRC succeeded in creating a platform for (some of) the victims and perpetrators of apartheid horrors to speak out, it fell short of instituting material changes in the fabric of South Africa's profound social inequalities, divisions and injustices. Its individualistic emphasis on perpetrators and victims, as well as the Commission's commitment to steering narratives towards peace and forgiveness, and away from anger, revenge or outrage (Statman 2000), constrained the TRC from pursuing wider societal reformations and re-imaginings. Today, South Africa remains a deeply segregated, unjust society.

\section{Migration in post-apartheid South Africa}

Although forced segregation is a thing of the past, South Africa continues to maintain informal racialized spaces through patterns of migration that maintain privilege and exclusion. The right to freedom of movement in public spaces after apartheid made it (theoretically) possible for all citizens to migrate to and within urban centres, rapidly changing the racial profile of South Africa's towns and cities. Areas that had once been reserved for the white minority were open to all. Apartheid government mechanisms that had controlled the flow and subjects of migration were dismantled and new flows and subjects emerged. Yet this migration into (previously) white spaces has not always led to integration (Lemanski 2006).

As previously excluded groups entered public spaces, whites began a parallel migration, abandoning business and residential urban centres in favour of suburban enclaves (Ballard 2004; Christopher 2000). These migrations (re) produced patterns of segregation and inequality that were familiar elsewhere, such as Farley's (1978) depiction of the "chocolate city, vanilla suburbs" 


\section{Kevin Durrheim and Amy Jo Murray}

shows. "White flight" and the flight of capital are not uniquely South African phenomena, but they have arisen from the specific context of colonization and apartheid.

Material and institutional walls and violence that had previously kept the constructed black "other" from entering the city limits were removed. But as Africans now migrated into historically whites-only places and institutions, they were confronted with racist attitudes that echoed the frontier. Employing discourses of crime, fear and increased ambiguity and insecurity (Durington 2009; Lemanski 2004), primarily (though not exclusively) white South Africans have established measures to ensure improved safety and security in the midst of perceived and actual urban municipal mismanagement (Ballard and Jones 2015).

Soon these individualized practices produced more extreme forms of collective control through the formation of and migration to gated communities (Ballard and Jones 2015; Durington 2009; Lemanski 2004). Gated communities range from fortified and enclosed pre-existing neighbourhoods with restricted street access through to the development of new residential communities, in the form of eco-estates, golf estates and other lifestyle-themed estates. In South Africa, luxury residential estates are the only residential properties that have increased in value over the past ten years (New World Wealth 2019a), making them very highly sought after among the elite. In fact, only the USA has more residential estates than South Africa (New World Wealth 2019b).

Gated communities are a worldwide phenomenon of middle- to upperclass citizens retreating into enclaves for increased security, improved services and decreased engagement with wider society, especially the urban poor (Blakely and Snyder 1997; Blandy and Lister 2005; Low 2003). Yet these fundamental features of gated communities take on particular meanings in societies that have undergone political and socio-economic transformation, as in the case of post-apartheid South Africa (Hook and Vrdoljak 2002; Lemanski 2004). Indeed, there are concerns that gated communities "effectively recreate the apartheid city and thwart post-apartheid goals of urban integration and inclusion" (Lemanski et al. 2008, p. 135), especially in light of the fact that more that $40 \%$ of South African individuals with a net worth of US \$1 million reside in some form of gated community or lifestyle estate (New World Wealth 2019b). For many wealthy (primarily, but not exclusively, white) South Africans, migration to gated communities is a symbolic and material exercise of control and power in the face of ambiguity and insecurity since the transition from apartheid (Ballard 2004; Hook and Vrdoljak 2002; Lemanski 2004). The privatized regulation of such residences through body corporates has facilitated a system of effective and insular private governance that is perceived to contrast starkly with the municipal (mis)management and politics of the outside world (Ballard and Jones 2014). It also allows members of gated communities to divorce themselves from civic responsibilities and engagement (Hook and Vrdoljak 2002). This leads 
Lemanski et al. (2008, p. 136) to argue that "gating in South Africa is perceived as a means to wield one's own power, as a private property owner, rather than submit to the state, as a citizen".

\section{The new frontier}

Socially, restricting access to gated communities enables "the exclusion of strangers, often racially defined" (Ballard and Jones 2014, p. 297). In addition, "enclaves do not just respond to difference and fear, but actually deepen segregation and reinforce fear by excluding difference and limiting social mixing" (Lemanski 2004, p. 108). This racial and economic migration has reinforced old privilege and exclusion, leading some to label the system of gated communities as "the new apartheid" (Lemanski 2004). Within these walls, the fear of crime, criminal others and outsiders has become even more entrenched in their inhabitants' social imagination. From the outside, those who are excluded view migration behind walls as yet another rejection, another form of distancing. It is a new frontier.

In addition to the migration of people, post-apartheid cities have seen a movement of capital from urban centres that have largely been abandoned by white residents, investment and business. This migration is exemplified by the relocation of the Johannesburg Stock Exchange from downtown Johannesburg to Sandton in 2000. While policies such as Black Economic Empowerment (BEE) have aimed to shift economic power from the minority white elite to the black majority by giving Africans investment and employment opportunities, this policy intervention - much like the TRC - has focused largely on individuals and has not reached its goals. In implementing this policy, the post-apartheid government held a tension between rapid economic growth, which was largely controlled by white financial investment, and economic redistribution through BEE or similar policies (Tangri and Southall 2008). Corporate investment, which was largely driven by white interests and capital, was given more prominence than policies such as BEE - which has been described furthermore as impacting only a few well-connected individuals instead of changing the underlying factors of socio-economic inequality (Tangri and Southall 2008).

This has allowed white privilege to persist in an ostensibly desegregated society. Symbolic and material luxury attached to capital have become bound up with new spaces where the elite live and work: gated communities, office parks and edge cities that are largely self-contained and separate from the perceived disorder of city centres (Beavon 2004; Michel and Scott 2005). The new decentralized urban spaces outside the old urban centre (Garreau 1991) are vividly portrayed by Kitchin's (cited in Michel and Scott 2005, p. 106) description of La Lucia-Umhlanga Ridge (an edge city outside of Durban) as "island(s) of wealth surrounded by a sea of poverty".

While the migration of individuals to spaces that ensure greater safety and security can be viewed as an exercise of free will, "its collective consequences 
produce a divided city, at odds with post-apartheid ideals of unity and equality" (Lemanski et al. 2008, p. 133). Places such as gated communities and edge cities are infused with migrations that lead to racialized segregation, which is highly consequential in a post-apartheid context. These are places where the elite shop and the disempowered serve; where the elite live and the subaltern clean; where the elite buy and own expensive cars and the racialized poor use public transport to commute to and from places of wealth and privilege where they work but do not seem to belong. Poor South Africans migrate daily in and out of these spaces, while the wealthy (usually white) residents retreat further into their enclaves to which they have permanently migrated, behind symbolic and material walls of exclusion and privilege. All of this tends to more deeply segregate a society that is now a mere shadow of what it had hoped to become.

\section{Conclusion}

South Africa's history has been a story of divisions, as social groups have created and contested frontiers that (re)inscribe power, privilege and property. Although this has reproduced segregation - which is often the point of interest for policymakers and researchers - in this chapter we have shifted our focus from segregation to migration, the dynamic process by which South African society and social attitudes have been formed. Segregation is a snapshot of socio-spatial relations at a specific point in time, whereas migration considers the ever-changing push and pull that keeps people moving towards and away from each other. Migration describes a flow of people, and the movement of social groups who act in relation to their social worlds, establishing and maintaining frontiers that allow, restrict and avoid contact.

The latest stage of this migration has (re)produced forms of segregation, exclusion and distance that fly in the face of the founders of South Africa's new democracy. In the current post-Rainbow Nation era, we continue to confront the realities of (racialized) privilege that migration instantiates and that make social justice so elusive. Despite the transitional goals of unity and integration, we continue to migrate away from racialized others as we live and move in ways that echo the colonial and apartheid patterns of our history. As Rainbow Nation dreams become shadows, property laws and constitutional values are continually circumnavigated by elite citizens as the subaltern are left in slum-like conditions.

Any intergroup contact that occurs in South Africa necessarily occurs within the broader assemblage of racialized privilege. Rather than looking to inter-individual contact at specific moments, we have argued that we need to look to histories of inter-group contact, which in the South African context are embedded in a series of migrations. Social change - and social justice depend then on the ability to intervene in the forces that constrain intergroup contact as patterns of daily lived experience. It might only be through radical 
economic reforms that the current flows of migration can be redirected. Investment that is aimed at places and people who have been excluded from social justice so far needs to be seriously considered, as an alternative to investment into capital flows that only shore up more privilege, power and property for racialized elites. The redistribution of capital on a broad scale, not just among individuals but at community and corporate levels, is necessary. If investment continues to focus on creating spaces of increasing luxury, safety and security that only a few elites can enjoy, we risk recreating and reproducing the apartheid era that continues to haunt us. We will essentially become a society that has migrated away from social justice.

\section{Note}

1 Fallist movements are protest and awareness movements calling for the decolonization of education to illuminate the deep roots of white privilege in South Africa. The fallist movements are led by predominantly black students and include protests such as \#RhodesMustFall and \#FeesMustFall (see Lishivha 2019).

\section{References}

Arndt, Jochen S. "What's in a word? Historicising the term 'caffre' in European discourses about Southern Africa between 1500 and 1800". Journal of Southern African Studies, vol. 44, no. 1, 2018, pp. 59-75.

Ballard, Richard. "Assimilation, emigration, semigration, and integration: 'White' peoples' strategies for finding a comfort zone". Under construction: "Race" and identity in South Africa today, edited by Natasha Distiller and Melissa E. Steyn, Sandton, Heinemann, 2004, pp. 51-66.

Ballard, Richard, and Gareth A. Jones. "The sugarcane frontier: Governing the production of gated space in KwaZulu-Natal". Urban governance in post-apartheid cities: Modes of engagement in South Africa's metropoles, edited by Christoph Haferburg and Marie Huchzermeyer, Stuttgart, Borntraeger Science Publishers, 2014, pp. 295-312.

Barlow, Fiona Kate, Stefania Paolini, Anne Pedersen, Matthew J. Hornsey, Helena R. M. Radke, Jake Harwood, Mark Rubin, and Chris G. Sibley. "The contact caveat: Negative contact predicts increased prejudice more than positive contact predicts reduced prejudice". Personality and Social Psychology Bulletin, vol. 38, 2012, pp. 1629-1643.

Beavon, Keith. Johannesburg: The making and shaping of the city. Pretoria, University of South Africa Press, 2004.

Bettencourt, Leonor, John Dixon, and Paula Castro. "Understanding how and why spatial segregation endures: A systematic review of recent research on intergroup relations at a micro-ecological scale". Social Psychological Bulletin, vol. 14, 2019, pp. 1-24.

Blakely, Edward James, and Mary Gail Snyder. Fortress America: Gated communities in the United States. Washington, DC, Brookings Institution Press, 1997.

Blandy, Sarah, and Diane Lister. "Gated communities: (Ne)gating community development?” Housing Studies, vol. 20, no. 2, 2005, pp. 287-301. 
Cakal, Huseyin, Miles Hewstone, Gerhard Schwär, and Anthony Heath. "An investigation of the social identity model of collective action and the 'sedative' effect of intergroup contact among black and white students in South Africa”. British Journal of Social Psychology, vol. 50, 2011, pp. 606-627.

Cell, John Whitson. The highest stage of white supremacy. Cambridge, Cambridge University Press, 1982.

Christopher, A. J. The atlas of changing South Africa. London, Routledge, 2000.

Clark, Kenneth B., "The social scientist as an expert witness in civil rights legislation”. Social Problems, vol. 1, no. 1, 1953, pp. 5-10.

Clarno, Andy. "Rescaling white space in post-apartheid Johannesburg". Antipode, vol. 45, no. 5, 2013, pp. 1190-1212.

Crisp, Richard J., and Rhiannon N. Turner. "Can imagined interactions produce positive perceptions?: Reducing prejudice through simulated social contact". American Psychologist, vol. 64, no. 4, 2009, pp. 231-240.

Dixon, John, Kevin Durrheim, and Colin Tredoux. "Beyond the optimal contact strategy: A reality check for the contact hypothesis". American Psychologist, vol. 60, 2005, pp. 697-711.

Dixon, John, Kevin Durrheim, and Colin Tredoux. "Intergroup contact and attitudes towards the principle and practice of racial equality". Psychological Science, vol. 18, 2007, pp. 867-872.

Dixon, John, Kevin Durrheim, and Manuela Thomae. "The principle-implementation gap in attitudes towards racial inequality (and how to close it)". Advances in Political Psychology, vol. 38, s. 1, 2017, pp. 91-126.

Du Bois, W.E.B. The Souls of Black Folk. Oxford, Oxford University Press, 1903/2007.

Durington, Matthew. "Suburban fear, media and gated communities in Durban, South Africa". Home Cultures, vol. 6, 2009, pp. 71-88.

Durrheim, Kevin, and John Dixon. "Intergroup contact and the struggle for social justice". The Oxford handbook of social justice, edited by Phillip L. Hammack, New York, Oxford, 2018, pp. 367-378.

Evans, Matthew. "Structural violence, socioeconomic rights, and transformative justice". Journal of Human Rights, vol. 15, no. 1, 2016, pp. 1-20, doi:10.1080/ 14754835.2015.1032223.

Fanon, Frantz. The Wretched of the Earth. New York, Grove Press, 1961/2004.

Farley, Reynolds, Howard Schuman, Suzanne Bianchi, Diane Colasanto, and Shirley Hatchett. "'Chocolate city, vanilla suburbs:' Will the trend toward racially separate communities continue?" Social Science Research, vol. 7, no. 4, 1978, pp. 319-344.

Gaertner, S.L., Dovidio, J.F., and Bachman, B.A. "Revising the contact hypothesis: The induction of a common group identity". International Journal of Intercultural Relations, vol. 20, 1996, pp. 271-290.

Garreau, Joel. "Edge city": Life on the new frontier. New York, Doubleday, 1991.

Hook, Derek, and Michele Vrdoljak. "Gated communities, heterotopia and a 'rights' of privilege: A 'heterotopology' of the South African security-park”. Geoforum, vol. 33, no. 2, 2002, pp. 195-219.

Kende, Judit, Karen Phalet, Wim Van den Noortgate, Aycan Kara, and Ronald Fischer. "Equality revisited: A cultural meta-analysis of intergroup contact and prejudice". Social Psychological and Personality Science, vol. 9, no. 8, 2018, pp. 887-895.

Lau, Ursula, Kevin Durrheim, and Lisa S. Young. "Place detachment and the psychology of nonbelonging: Lessons from Diepsloot informal settlement". Changing 
senses of place: Navigating global challenges, edited by Christopher M. Raymond, Daniel R. Williams, Andrés Di Masso, and Timo von Wirth. Cambridge, Cambridge University Press, 2021, pp. 103-115.

Lemanski, Charlotte L. "Desegregation and integration as linked or distinct? Evidence from a previously 'white' suburb in post-apartheid Cape Town". International Journal of Urban and Regional Research, vol. 30, no. 3, 2006, pp. 564-586.

Lemanski, Charlotte L. "A new apartheid? The spatial implications of fear of crime in Cape Town, South Africa". Environment \& Urbanization, vol. 6, no. 2, 2004, pp. 101-111.

Lemanski, Charlotte L., Karina Landman, and Matthew Durington. "Divergent and similar experiences of 'gating' in South Africa: Johannesburg, Durban and Cape Town". Urban Forum, vol. 19, 2008, pp. 133-158.

Lemmer, Gunnar, and Ulrich Wagner. "Can we really reduce ethnic prejudice outside the lab? A meta-analysis of direct and indirect contact interventions". European Journal of Social Psychology, vol. 45, no. 2, 2015, pp. 152-168.

Lishivha, Welcome. "The fallist movement and the changes it has made". The Mail \& Guardian, 3 May 2019, mg.co.za/article/2019-2005-03-00-the-fallist-movement-a nd-the-changes-it-has-made/.

Low, Setha M., Behind the gates: Life, security and the pursuit of happiness in fortress America. London, Routledge, 2003.

MacCrone, I.D. Distribution of group-attitudes towards the native, 1933. Print.

MacCrone, I.D. Race attitudes in South Africa: Historical, experimental, and psychological studies. Johannesburg, Witwatersrand University Press, 1957.

Maoz, Ifat. "Does contact work in protracted asymmetrical conflict? Appraising 20 years and four major models of reconciliation-aimed planned encounters between Israeli Jews and Palestinians". Journal of Peace Research, vol. 48, 2011, pp. 115125.

Michel, D.P. and D. Scott. "The La Lucia-Umhlanga Ridge as an emerging 'edge city". South African Geographical Journal, vol. 87, no. 2, 2005, pp. 104-114.

New World Wealth. AfrAsia Bank South Africa wealth report 2019. Sandton, New World Wealth, 2019a, https://e.issuu.com/embed.html?u=newworldwealth\&d= south_africa_2019.

New World Wealth. 2019 estate ratings: The top residential estates in South Africa. Sandton, New World Wealth, 2019b, https://e.issuu.com/embed.html?u=new worldwealth\&d=estate_ratings_sa_2019.

Nyamnjoh, Francis B. \#RhodesMustFall: Nibbling at resilient colonialism in South Africa. Bamenda, Langaa Research and Publishing Common Initiative Group, 2016.

Packard, Randall M. "The 'healthy reserve' and the 'dressed native': Discourses on black health and the language of legitimation in South Africa". American Ethnologist, vol. 16, no. 4, 1989, pp. 686-703.

Pettigrew, Thomas F. "Racial change and social policy". The ANNALS of the American Academy of Political and Social Science, vol. 441, no. 1, 1979, pp. 114-131.

Pettigrew, Thomas F., and Miles Hewstone. "The single factor fallacy: Implications of missing critical variables from an analysis of intergroup contact theory". Social Issues and Policy Review, vol. 11, no. 1, 2017, pp. 8-37.

Pettigrew, Thomas F., and Linda R. Tropp. "How does intergroup contact reduce prejudice? Meta-analytic tests of three mediators". European Journal of Social Psychology, vol. 38, no. 6, 2008, pp. 922-934. 


\section{Kevin Durrheim and Amy Jo Murray}

Pettigrew, Thomas F., and Linda R. Tropp. "A meta-analytic test of intergroup contact theory". Journal of Personality and Social Psychology, vol. 90, no. 5, 2006, pp. 751-783.

Statman, James M. "Performing the truth: The social-psychological context of TRC narratives". South African Journal of Psychology, vol. 30, 2000, pp. 23-32.

Tangri, Roger, and Roger Southall. "The politics of black economic empowerment in South Africa". Journal of Southern African Studies, vol. 34, no. 3, 2008, pp. 699-716.

Tshishonga, Ndwakhulu. "The legacy of apartheid on democracy and citizenship in post-apartheid South Africa: An inclusionary and exclusionary binary?" AFRIKA Journal of Politics, Economics and Society, vol. 9, no, 1, 2019, pp. 167-191.

Turner, Rhiannon N., Miles Hewstone, Alberto Voci, Stefania Paolini, and Oliver Christ. "Reducing prejudice via direct and extended cross-group friendship". European Review of Social Psychology, vol. 18, no. 1, 2007, pp. 212-255.

Wright, Stephen, Arthur Aron, Tracy McLaughlin-Volpe, and Stacy A. Ropp. "The extended contact effect: Knowledge of cross-group friendships and predjudice". Journal of Personality and Social Psychology, vol. 73, no. 1, 1997, pp. 73-90.

Zhou, Shelly, Elizabeth Page-Gould, Arthur Aron, Anne Moyer, and Miles Hewstone. "The extended contact hypothesis: A meta-analysis on 20 years of research". Personality \& Social Psychology Review, vol. 23, no. 2, 2019, pp. 132-160. 